\title{
Structure and Physicomechanical Properties of Superhard Multicomponent Multilayer (TiAlCrY/Zr)/(TiAlCrYN/ZrN) Coatings with Double Modulation Period of the Structure
}

\author{
V.Yu. Novikov'1, V.M. Beresnev², D.A. Kolesnikov¹, O.N. Ivanov¹, S.V. Lytovchenko², O.V. Glukhov², \\ D.V. Gorokh ${ }^{2}$, A.O. Kozachenko ${ }^{1}$, E.V. Krytsyna ${ }^{1}$, V.V. Sirota ${ }^{4}$ \\ ${ }^{1}$ Belgorod State National Research University, 85, Pobiedy St., 308015 Belgorod, Russian Federation \\ ${ }^{2}$ V.N. Karazin Kharkiv National University, 4, Svobody Sq., 61022 Kharkiv, Ukraine \\ ${ }^{3}$ National University of radio electronics, 14, Nauki Boul., 61166 Kharkiv, Ukraine \\ ${ }^{4}$ V.G. Shukhov Belgorod State Technological University, 46, Kostyukov St., 308012 Belgorod, Russian Federation
}

(Received 27 February 2019; revised manuscript received 08 April 2019; published online 15 April 2019)

\begin{abstract}
The paper describes the acquisition, establishment of mechanisms and patterns of formation of the phase composition and structure of multilayer coatings of the (TiAlCrY)N/ZrN system with a single and of the (TiAlCrY/Zr)/(TiAlCrY)N/ZrN systems with a double modulation period by vacuum-arc deposition. The targets were located along one straight line at equal distances from the perpendicular axis on which the substrates were placed. The rotation of the axis with the substrates was carried out either continuously or with a fixed delay at the evaporators. The coatings of both systems are distinguished by a high degree of laminarity of the layers. The (TiAlCrY)N/ZrN system coatings have a pronounced layered periodic structure in the entire coating volume. The modulation period (total thickness of the bilayer) of such a structure is about $30 \mathrm{~nm}$. Two modulation periods are clearly visible in the (TiAlCrY/Zr)/(TiAlCrYN/ZrN) system coatings. One period approximately coincides with the modulation period of the samples of the (TiAlCrY/Zr) N system and is about $30 \mathrm{~nm}$. The second modulation period is about 1.3 microns. It includes 48 bilayers. The influence of the partial pressure of nitrogen in the chamber on the nitrogen content in the coatings, their hardness and adhesive strength were studied. A significant increase in the hardness of 68.22 $\mathrm{GPa}$ and the adhesion strength of the coatings with a double modulation period of the structure was revealed. A fundamentally new technological approach to the process of obtaining multilayer coatings has been proposed.
\end{abstract}

Keywords: Multilayer coatings, Structure modulation period, Microhardness, Adhesive strength, Phase and elemental composition.

DOI: 10.21272/jnep.11(2).02027

PACS numbers: 68.55.Jk, 68.65.Ac

\section{INTRODUCTION}

Early studies have shown that films based on nitrides of refractory metals $[1,2]$ are unique materials for creating multilayer coatings. They have improved physical, chemical, mechanical and tribological properties due to the achievement of the necessary technological parameters, namely, the thickness of the layers in the period??, the partial pressure of the gas atmosphere, the energy factor determined by the magnitude of the displacement potential during precipitation. Thus, one can change the characteristics of the coating obtained by changing its value and type of gas atmosphere. Recently, the concept of creating protective coatings in the form of multi-element multilayer systems [3], which can withstand high temperatures, have a low coefficient of friction, resistance to wear and high surface loads, has been developed. Therefore, the relevance to the creation of new coatings has increased significantly. Despite the large number of studies on the technology of obtaining and studying the properties of multi-element nitride coatings, it is of great interest to use them as layers of a multi-layer coating based on nitrides of multi-element alloys [4].

The purpose of the present work is to obtain multilayer coatings with high mechanical properties by vacuum arc deposition from a material consisting of nitride-forming elements of the metals $\mathrm{Ti}, \mathrm{Al}, \mathrm{Cr}, \mathrm{Zr}, \mathrm{Y}$.

\section{EXPERIMENTAL TECHNIQUE}

The coating was deposited from two cathodes located opposite each other. The first cathode was made of the $\mathrm{Ti}_{0.57} \mathrm{Al}_{0.36} \mathrm{Cr}_{0.06} \mathrm{Y}_{0.01}$ alloy. It was produced by vacuum arc melting in an atmosphere of high-purity argon. The obtained ingot was melted down 6-7 times with a cooling rate of about $50 \mathrm{~K} / \mathrm{s}$ for the final homogenization of the composition. The second cathode was of pure $\mathrm{Zr}$. The formation of a multilayer system was carried out by vacuum-arc evaporation on a Bulat installation by deposition of layers with simultaneously operating magnetrons and a fixed substrate, which rotated at a speed of $8 \mathrm{rpm}$, turning in the process of working side alternately to one or the other cathode. Two series of samples were made. In the first case, nitrogen was continuously supplied to the chamber in such a way that the residual gas pressure was $0.58 \mathrm{~Pa}$. The time of layered coatings deposition was 1.5 hours. As a result, layers of (TiAlCrY)N and $\mathrm{ZrN}$ were formed alternately during the deposition process. The total coating thickness was about 8 microns. The scheme for obtaining the second series of samples was as follows: the substrate, as in the first case, rotated at a speed of $8 \mathrm{rpm}$. However, the pressure in the chamber was cycled, first 1 minute at $P_{\mathrm{N}}=0.01 \mathrm{~Pa}$, then 5 minutes at $P_{\mathrm{N}}=0.67 \mathrm{~Pa}$ for 3.5 hours. The total thickness of the coatings was $22 \div 25$ microns. Based on the experience of previous studies, the optimal voltage applied to the substrate during the formation of coatings based on 
nitrides of refractory metals is $U_{b}=-200 \mathrm{~V}$, as well as the partial pressure of nitrogen $P=0.6 \ldots 0.7 \mathrm{~Pa}$, which we chose in our experiments. The study of the surface morphology of the obtained coatings was carried out using a scanning electron microscope FEI Nova NanoSEM 450. The elemental composition of the samples was studied by analyzing the spectra of the characterristic $\mathrm{x}$-ray radiation generated by the electron beam in a scanning electron microscope. The spectra were taken with an PEGASUS energy dispersive X-ray spectrometer of EDAX company installed in a microscope. The phase-structural state was studied on a DRON-4-07 diffractometer in $\mathrm{Cu}-\mathrm{K}_{a}$ radiation. The hardness was measured with a Vickers diamond pyramid using microindentation on an Instron microhardness test device 402MVD with a load of $100 \mathrm{~g}$. Determination of adhesive and cohesive strength, resistance to scratching and elucidation of the mechanism of destruction of coatings was carried out using a scratch tester Revetest (CSM Instruments).

\section{EXPERIMENTAL RESULTS AND DISCUSSION}

Fig. 1 and Fig. 2 show the images of the surfaces, as

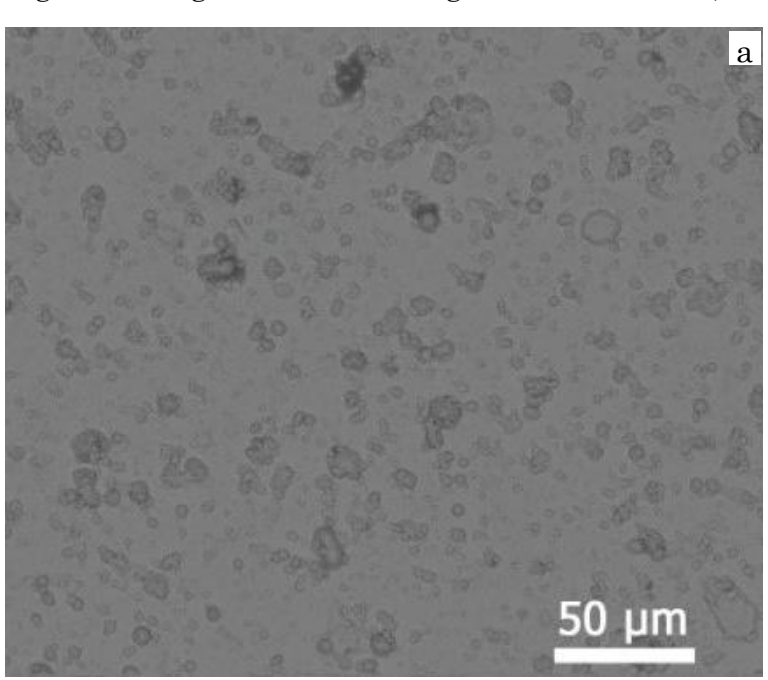

well as the cross sections of multilayer ( $\mathrm{TiAlCrY}$ ) N/ZrN coatings obtained at constant nitrogen pressure and of (TiAlCrY/Zr)/(TiAlCrYN/ZrN) coatings with cyclically varying nitrogen pressure.

The surface of multilayer coatings of both types is characterized by the presence of a droplet fraction and cathode particulates, which is typical of most vacuumarc condensates obtained from non-separated plasma flows. The sizes of droplet fractions vary within 1-10 $\mu \mathrm{m}$ (Fig. 1), along with this, the rare presence of particulates locally distorting the layered structure of the coating is recorded in the volume of condensates (see Fig. 2). The coatings of both systems are distinguished by a high degree of laminarity of the layers. The coatings of the (TiAlCrY)N/ZrN system have a pronounced layered periodic structure in the entire coating volume (Fig. 2a). The modulation period (total thickness of the bilayer) of such a structure is about $30 \mathrm{~nm}$. Two modulation periods are clearly seen in the (TiAlCrY/Zr)/(TiAlCrYN/ZrN) system coatings. One period approximately coincides with the modulation period of the samples of the system (TiAlCrY/Zr)N and is about $30 \mathrm{~nm}$. The second modulation period is about 1.3 microns. It includes 48 bilayers (see Fig. 2b).

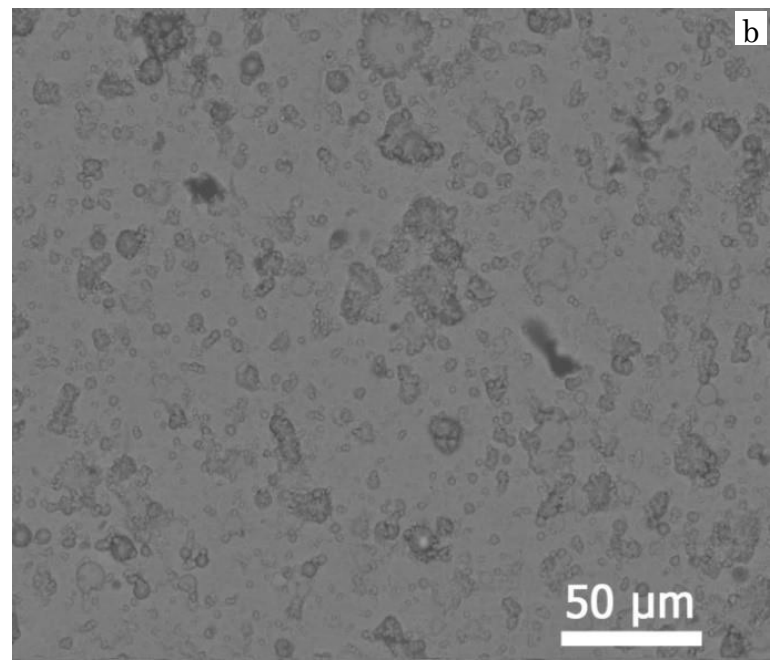

Fig. 1 - Surface images of the coatings of (TiAlCrY)N/ZrN (a) and (TiAlCrY/Zr)/(TiAlCrYN/ZrN) systems (b)
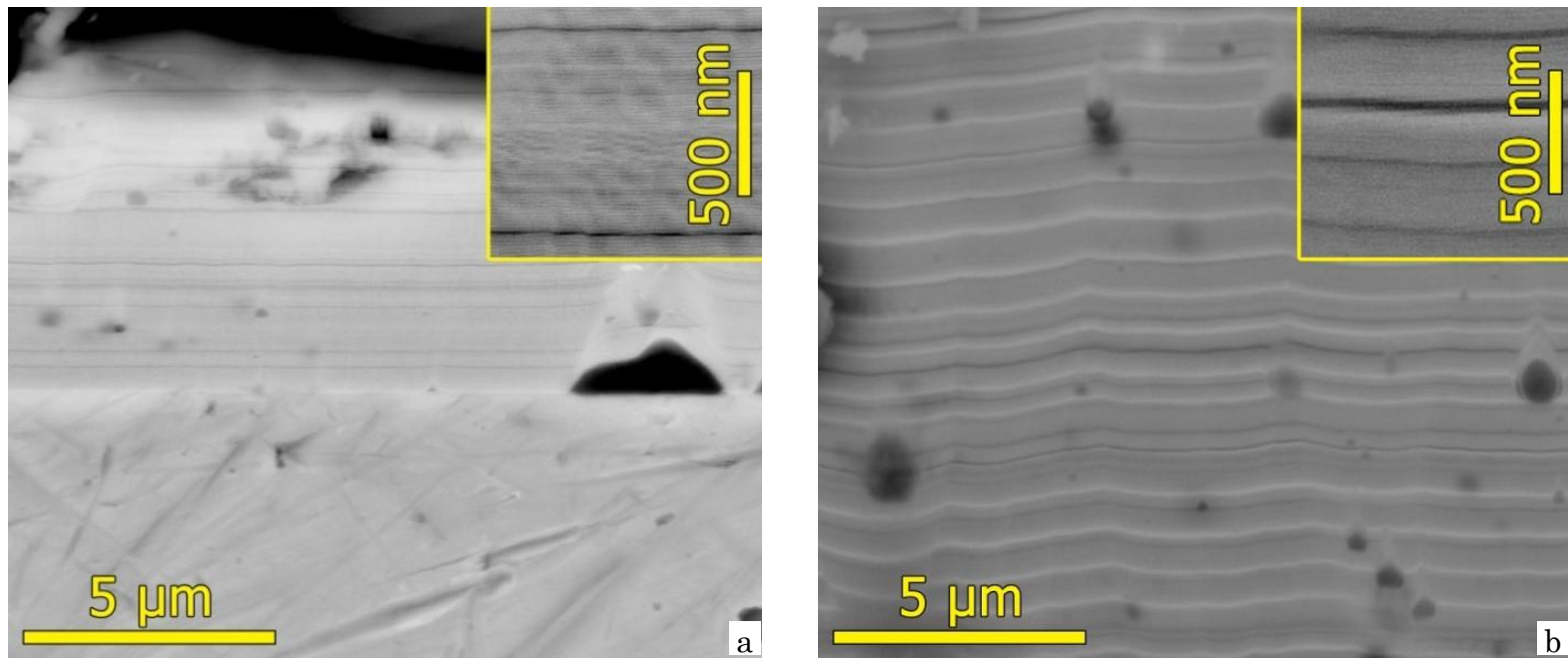

Fig. 2 - Images of transverse section of the coatings of (TiAlCrY)N/ZrN (a) and (TiAlCrY Zr)/(TiAlCrYN/ZrN) systems (b) 
The images in Fig. 2 are obtained using a backscattered electron detector. In this mode, the signal recorded from the surface of the sample is especially sensitive to changes in the elemental composition. As seen in the layered structure of the coatings, a change in the signal inside the periodic structure (macromodulation) is observed. This indicates a local redistribution of the element content within the macrolayers. Most likely, this is due to the redistribution of nitrogen inside the nanolayers, which is associated, in turn, with a change in the partial pressure of nitrogen during the coating deposition with a double modulation period.

Fig. 3 and Fig. 4 show the energy dispersive spectra, which present the stoichiometry of the composition of the obtained multilayer coatings.

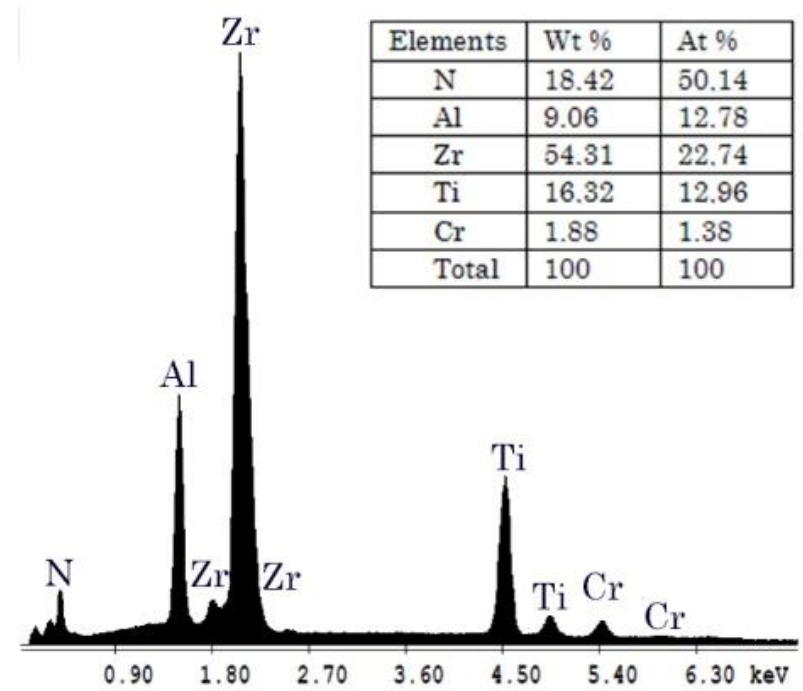

Fig. 3 - The part of the energy-dispersive spectrum and the elemental composition of the (TiAlCrY)N/ZrN multilayer coating determined from the spectrum

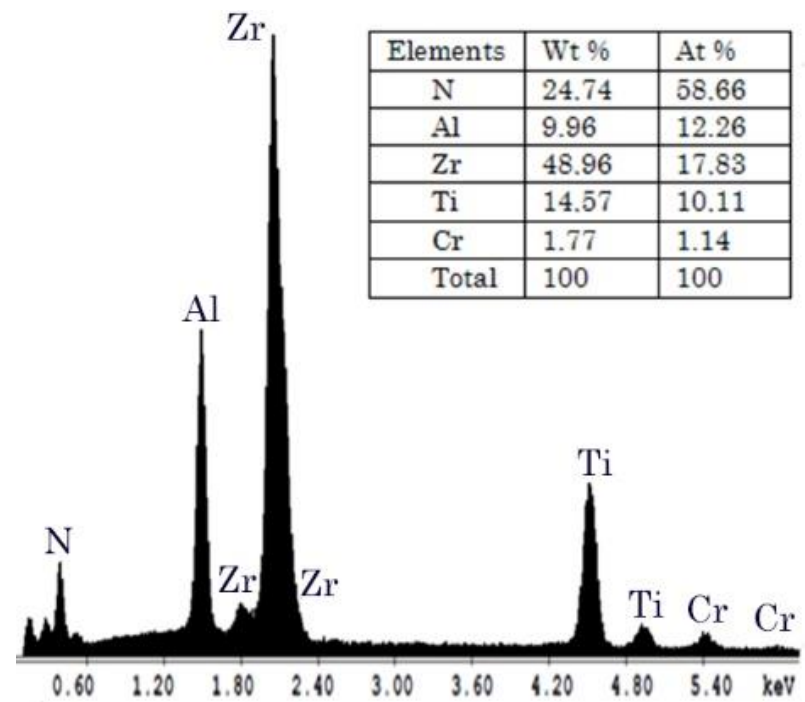

Fig. 4 - The part of the energy-dispersive spectrum and the elemental composition of the (TiAlCrY/Zr)/(TiAlCrYN/ZrN) multilayer coating determined by the spectrum

Elemental analysis shows a strong difference in the composition of the coatings from the composition of the cathode, especially in elements, such as Cr and Y. This is due to the fact that for these elements, which are the most refractory of the target, the partial vapor pressure during the spraying process is much less than for $\mathrm{Al}$ and Ti. Therefore, their concentration in the coatings is lower than in the target. Given that the concentration of $\mathrm{Y}$ in the target was about $1 \%$, this element is not observed in the spectrum of coatings, since its concentration is most likely lower than $0.1 \%$, which is the detection limit of this technique.

The characteristic X-ray spectra were collected from the surface of the coatings. The energy of the electron beam with which the x-rays were generated was $20 \mathrm{kV}$. This means that the depth of the region in which $\mathrm{x}$-ray radiation was excited is about 3 microns with an average coating density of about $5 \mathrm{~g} / \mathrm{cm}^{3}$. This means that the elemental composition was determined averaged over several dozen nanolayers. The high nitrogen content in both types of coatings indicates their high nitrogen stoichiometry. It should also be noted that in a coating with a double modulation period, the average nitrogen concentration is higher than in the sample, in which nitrogen was fed into the chamber continuously. Based on this, we can draw two conclusions. First, an increase in the partial pressure of nitrogen in the chamber leads to an increase in the nitrogen content in the coating. Secondly, despite the fact that $1 / 6$ of the time nitrogen was not supplied to the chamber, the average nitrogen content still remains high in the sample of the coatings of the (TiAlCrY/Zr)/(TiAlCrYN/ZrN) system. Most likely, this was due to the fact that during coating deposition the substrate heats up (based on the experience of previous experiments up to $250 \div 300{ }^{\circ} \mathrm{C}$ ), and when nitrogen is fed into the chamber, the previous layers deposited with a low nitrogen vapor pressure have time to nitriding in the process of applying the following layers. In support of this hypothesis, electron microscopic images from transverse layers appear, on which contrasting overlaps are visible, indicating diffusion processes occurring during the deposition of coatings. It should be noted that, despite the good diffusion of nitrogen, there is no blurring of the boundaries of nanolayers. This suggests that the diffusion coefficients for metals in nitride coatings at these temperatures are significantly lower than for nitrogen one.

Studies of the phase composition of the coatings were carried out (Fig. 5 and Fig. 6). Analysis of samples with (TiAlCrY)N/ZrN coatings showed the presence of two phases of nitrides, namely TiAlCrYN and $\mathrm{ZrN}$ with an FCC lattice. In addition, there are lines from the substrate. The lattice parameter of the $\mathrm{ZrN}$ is $a=4.590 \AA$, the CSR size of this phase is $D=5.4 \mathrm{~nm}$ at the level of microdistortion of $\varepsilon=4.79 \cdot 10^{-3}$. The lattice parameter of the complex nitride (TiAlCrY)N is equal to $a=4.203 \AA$. The substructural characteristics of this phase could not be determined. The intensity distribution of diffraction lines from both phases indicates the presence of weak (111) and (100) texture. I.e. the grains of both nitrides are predominantly oriented along the $\{100\}$ and $\{111\}$ close-packed planes parallel to the surface of the coatings.

Analysis of the obtained diffraction spectra of the (TiAlCrY/Zr)/(TiAlCrYN/ZrN) coatings with a double modulation period of the structure shows the formation of phases with a cubic (FCC) crystal lattice in both 
nanolayers of multilayer coatings, namely (TiAlCrY)N and $\mathrm{ZrN}$, similar to the first type of coatings. The $\mathrm{ZrN}$ lattice parameter is $a=4.577 \AA$, the CSR size of this phase is $D=3.5 \mathrm{~nm}$, the level of microdistortion is $\varepsilon=\leq 1 \cdot 10^{-4}$, that is, the CSR size only contributes to the line broadening. The lattice parameter of the complex nitride is $a=4.209 \AA$; it was not possible to determine the substructural characteristics of this phase. A weak (100) texture is observed in the coating, that is, the grains of both nitrides have a preferential orientation by $\{100\}$ crystallographic planes parallel to the surface of the coatings.

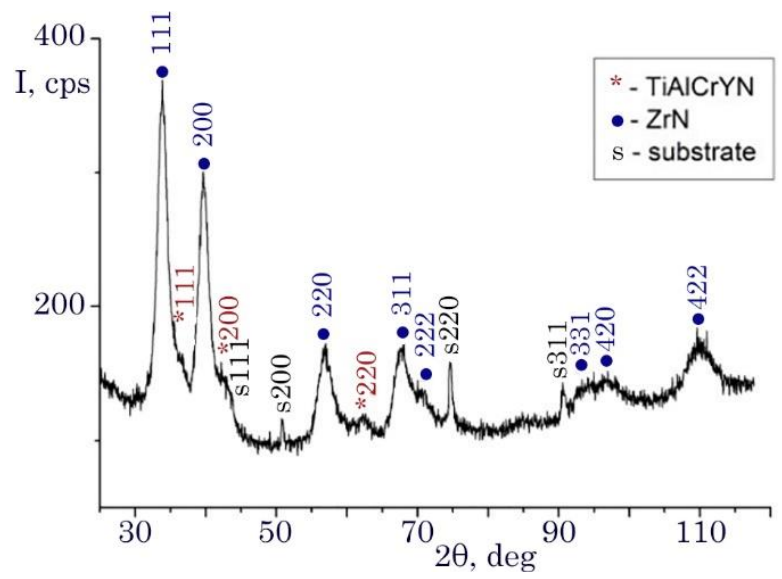

Fig. 5 - The plot of the diffraction spectrum of the multilayer (TiAlCrY)N/ZrN coating

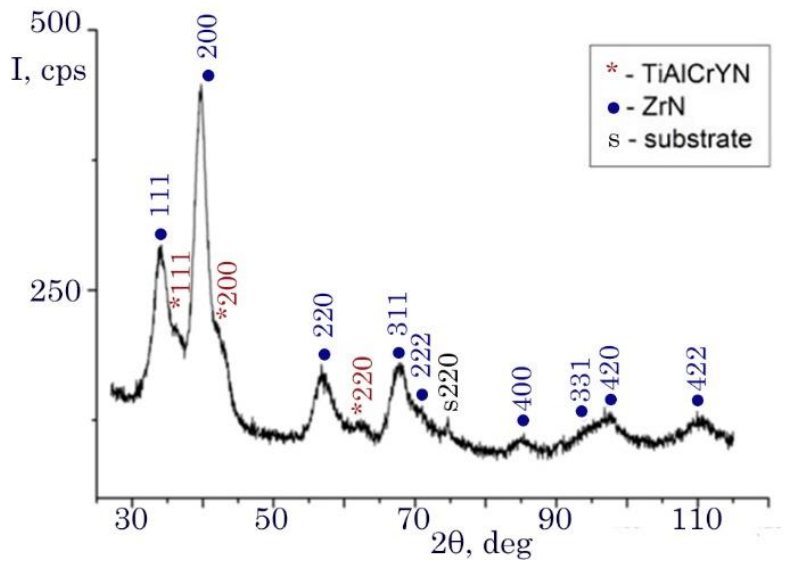

Fig. 6 - The plot of the diffraction spectrum of the multilayer (TiAlCrYN/ZrN)/(TiAlCrY/Zr) coating

The separation of the overlapping diffraction lines into components (Fig. 7) for both types of coatings showed that the lines of both phases have approximately the same half width, that is, the CSR size of these nitrides is approximately the same.

It should be noted that in the diffraction spectra of the (TiAlCrY/Zr)/(TiAlCrYN/ZrN) coatings there are no phases other than in the(TiAlCrY)N/ZrN coatings. This also argues in favor of the hypothesis about the nitriding of layers of coatings applied without nitrogen in the process of deposition of coatings with the supply of nitrogen into the chamber.

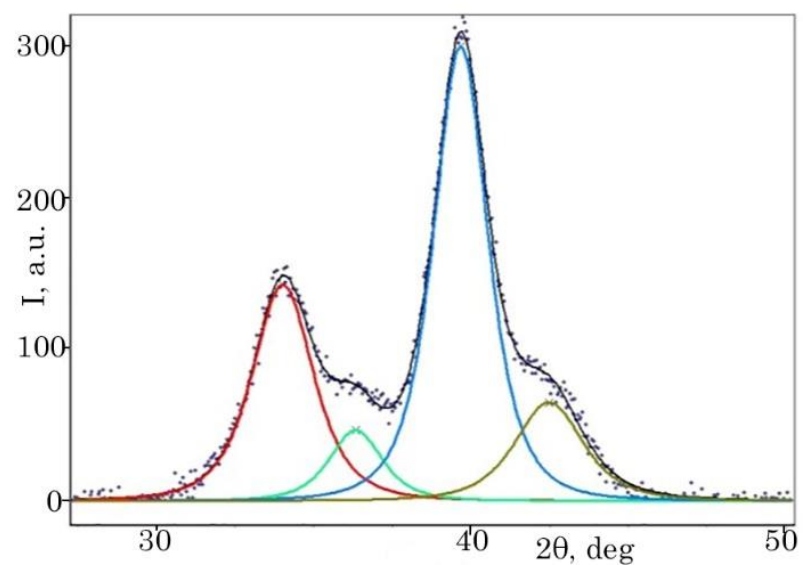

Fig. 7 -Separation of overlapping diffraction lines into components

The hardness of the coatings (TiAlCrYN/ZrN) and (TiAlCrY/Zr)/(TiAlCrYN/ZrN) was studied. The averaged results of microhardness measurements are presented in Table 1. A small scatter of microhardness measurements (the spread of values was less than $6 \%$ ) indicates a high uniformity of the mechanical properties of the coatings.

Table 1 - The results of measuring the microhardness of multilayer coatings obtained with a constant and periodic supply of nitrogen into the chamber at a load of HV 0.1.

\begin{tabular}{|c|c|c|c|}
\hline Coating & $\begin{array}{c}\text { Partial } \\
\text { pressure of } \\
\text { nitrogen, Pa }\end{array}$ & $\begin{array}{c}\text { Nitrogen } \\
\text { content, } \\
\text { at.\% }\end{array}$ & $\begin{array}{c}\text { Micro- } \\
\text { hardness } \\
\text { HV, GPa }\end{array}$ \\
\hline TiAlCrYN/ZrN & 0.58 & 50.14 & 49.0 \\
\hline $\begin{array}{c}\text { (TiAlCrY/Zr)/ } \\
\text { (TiAlCrYN/ZrN) }\end{array}$ & $0.01 / 0.67$ & 58.66 & 68.22 \\
\hline
\end{tabular}

The investigation results of the hardness of the coatings indicate that a significant increase in hardness is observed with nanoscale thickness of the layers, which is achieved with continuous rotation of the substrate. This can be attributed to the size effect [5]. In addition, an increase in the partial pressure of nitrogen during coating deposition also leads to an increase in the nitrogen content in the coatings and, as a consequence, to an increase in the hardness of the coatings [6].

Using the method of scratch testing, studies of the process of destruction of the formed multilayer nitride coatings were carried out.

Studies of the process of destruction of the formed multilayer nitride coatings were performed using the method of scratch testing.

Two scratches were applied to the surface of the coating with a Rockwell C-type diamond spherical indenter with a radius of curvature of $200 \mu \mathrm{m}$ under continuously increasing load. At the same time, the power of the acoustic emission (AE) signal, the friction coefficient and the indenter penetration depth, as well as the value of the normal load were recorded.

The dependence of the friction coefficient, acoustic emission on the load on the coated samples is presented in Fig. 8, and Fig. 9 shows the photographs of the surface of the (TiAlCrY/Zr)/(TiAlCrYN/ZrN) coating during the tests to determine the adhesive/cohesive strength. 

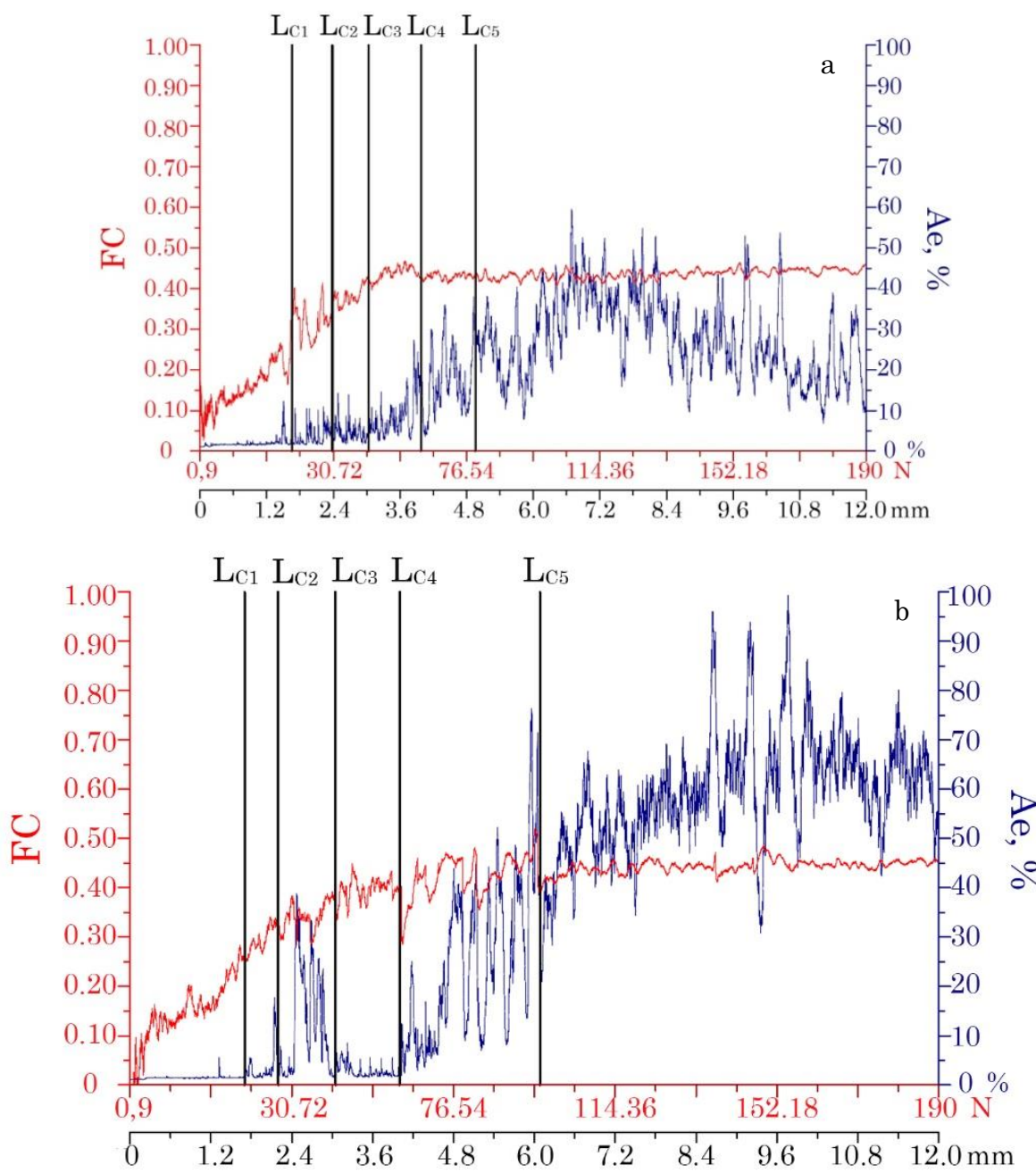

Fig. 8 - The averaged values of the friction coefficient (left scale) and the amplitude of acoustic emission (right scale) depending on the length of the passage and the applied force during the dynamic introduction of the diamond indenter into the surface of the (TiAlCrY)N/ZrN (a) and (TiAlCrY/Zr)/(TiAlCrYN/ZrN) (b) coatings

The indenter penetrates into the surface of the coating at the beginning of the process (Fig. 8) (area $\mathrm{L}_{\mathrm{Cl}}$ ), while the coating resists the penetration of the indenter, the friction coefficient increases non-monotonically due to surface roughness, but the amplitude of acoustic emission (AE) remains almost unchanged. Subsequently, the amplitude level of the AE changes and the friction coefficient also changes; however, the indenter penetration depth increases slightly due to an increase in the load. The subsequent increase in the load (region $\mathrm{L}_{\mathrm{C} 2}-\mathrm{L}_{\mathrm{C} 3}$ ) leads to non-monotonic change of the friction coefficient. Small chipping of the coatings is observed in the future with an increase in the load, the friction coefficient ( $\mathrm{L}_{\mathrm{C} 4}$ region) does not change, the amplitude of the acoustic emission peaks increases in the $L_{C 4}$ and $\mathrm{L}_{\mathrm{C} 5}$ regions, and the coatings abrade.

The snapshots of the wear tracks (see Fig. 9) give a visual characteristic of the processes taking place during scratch testing.

The results of loads for critical points $\mathrm{L}_{\mathrm{C}}$ are summarized (see Fig. 9, Table 2).

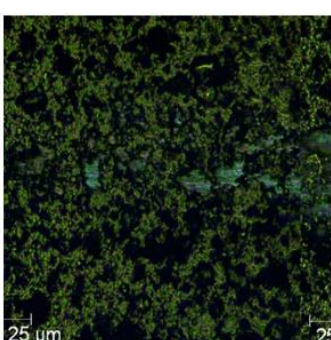

$\mathrm{L}_{\mathrm{C} 1}=27.67$

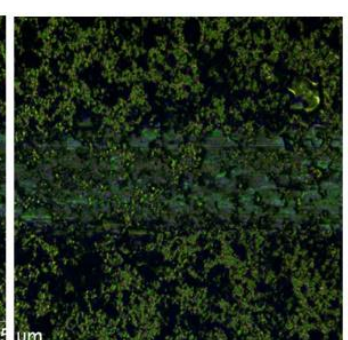

$\mathrm{L}_{\mathrm{C} 2}=35.54$

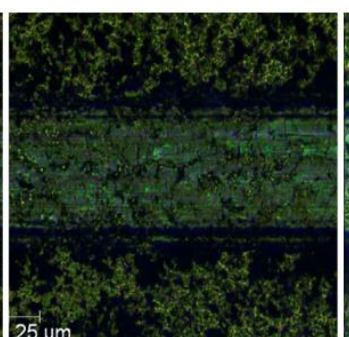

$\mathrm{L}_{\mathrm{C} 3}=48.93$

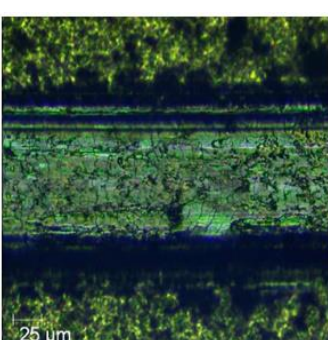

$\mathrm{L}_{\mathrm{C} 4}=63.98$

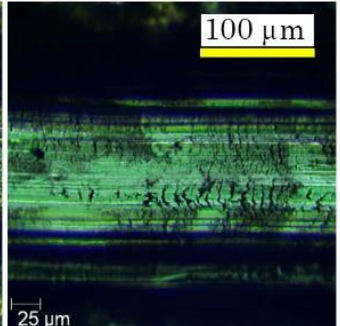

$\mathrm{L}_{\mathrm{C} 5}=96.75$

Fig. 9 - Photographs of scratches on the surface of a multilayer (TiAlCrY/Zr)/(TiAlCrYN/ZrN) coating obtained at $U_{b}=-200 \mathrm{~V}$, $P_{\mathrm{N}}=0.67 \mathrm{~Pa}$ 
Table 2 - The results of the adhesive testing of nitride coatings

\begin{tabular}{|c|c|c|c|c|c|}
\hline Coating & $\mathrm{L}_{1}$ & $\mathrm{LC}_{2}$ & $\mathrm{LC}_{\mathrm{C}}$ & $\mathrm{L}_{\mathrm{C} 4}$ & $\mathrm{~L}_{\mathrm{C} 5}$ \\
\hline TiAlCrYN/ZrN & 29.96 & 38.44 & 48.72 & 63.54 & 79.08 \\
\hline $\begin{array}{c}\text { (TiAlCrY/Zr)/ } \\
\text { (TiAlCrYN/ZrN) }\end{array}$ & 27.67 & 35.54 & 48.93 & 63.98 & 96.75 \\
\hline
\end{tabular}

It can be seen that the value of the critical load is high $\mathrm{L}_{\mathrm{C} 1}=27.67$ with hardness $\mathrm{HV} 0.1=68.25$ in the initial section. Smaller brittleness of a multilayer coating that combines superhard layers with less hard ones makes it possible to achieve higher values of adhesive strength with greater impact (as a criterion for adhesive strength, the critical load $\mathrm{L}_{\mathrm{C} 5}$ is used [7], leading to the destruction of the coating).

\section{CONCLUSIONS}

Multi-layer coatings of the TiAlCrYN/ZrN system with a modulation period of nanolayers of $30 \mathrm{~nm}$ and a coating of the (TiAlCrY/Zr)/(TiAlCrYN/ZrN) system with a double modulation period first is $30 \mathrm{~nm}$ and the second one is 1.3 microns have been investigated. It was found that the layered structure of both types of coatings has a high density and a good degree of laminarity. Coatings with a double modulation period showed a high hardness value of $68.2 \mathrm{GPa}$, which is not typical of conventional nitride coatings. The nitrogen content in both types of coatings is close to 50 at. \%, i.e. to the stoichiometric composition. It was established that an increase in the partial pressure of nitrogen in the chamber increases its content in the coatings, which increases their hardness. The gradient structure of nitrogen content in coatings with a double modulation period was revealed. In addition, the average nitrogen content in them is higher than in the coating with a single modulation period. This indicates the nitriding of the layers that were deposited at the time of shutdown of the supply of nitrogen into the chamber during the deposition of subsequent layers. A layered two-phase structure with a FCC lattice is formed in both types of coatings. The value of CSR for both nitride phases TiAlCrYN/ZrN and $\mathrm{ZrN}$ coincides. No additional phases were detected in (TiAlCrY/Zr)/(TiAlCrYN/ZrN) coating with a double modulation period as compared to TiAlCrYN/ZrN coatings.

\section{REFERENCES}

1. Nanostructured coatings (Ed. by A. Cavaleiro, J.T.M. De Hosson) (Springer-Verlag: Berlin: 2006).

2. Deqiang Yin, Zhenhai Xu, Jiling Feng,Yi Qin Deqiang Yin, Zhenhai Xu, Jiling Feng, Yi Qin, Manufacturing Rev. 1, 8 (2014).

3. J. An, Q.Y. Zhang, Mater. Character. 58, 439 (2007).

4. A.D. Pogrebnjak, O.M. Ivasishin, V.M. Beresnev, Usp. Fiz. Metal. 17(1), 1 (2016)

5. Wei Li, Ping Liu, Peter K. Liaw, Mater. Res. Lett. 6 No 4,199 (2018).

6. R.A. Andrievski, Surf. Coat. Tech. 201, 6112 (2007).

7. J. Valli, J. Vac. Sci. Technol. A 4, 3007 (1986).

\section{Структура та фізико-механічні властивості надтвердих багатошарових покриттів (TiAlCrY/Zr)/(TiAlCrYN/ZrN) з подвійним періодом модуляції структури}

В.Ю. Новіков ${ }^{1}$, В.М. Береснев², Д.А. Колесніков ${ }^{1}$, О.Н. Іванов르, С.В. Литовченко ${ }^{2}$, Д.В. Горох ${ }^{2}$ О.В. Глухов ${ }^{3}$, А.О. Козаченко ${ }^{1}$, Є.В. Крицина ${ }^{1}$ В.В. Сирота ${ }^{4}$

1 Белгородський Державний Національний Дослідницький Університет, вул. Перелоги 85, 308015 Белгород, Російська Федераиія

${ }^{2}$ Харківський Національний Університет ім. В.Н. Каразіна, пл. Свободи, 4, 61022 Харків, Украӥна

${ }^{3}$ Національний Університет Радіоелектроніки, Бульвар Науки, 14, 61166 Харків, Україна

${ }^{4}$ Белгородський Державний Технологічний Університет іл. В.Г. Шухова, вул. Костюкова, 46, 308012 Белгород, Російська Федерація

У роботі описуеться отримання, встановлення механізмів та закономірностей формування фазового складу, структури багатошарових покриттів системи (TiAlCrY)N/ZrN з одинарним і системи (TiAlCrY/Zr)/(TiAlCrY)N/ZrN з подвійним періодом модуляції методом вакуумно-дугового осадження. Мішені розташовували на одній прямій на рівних відстанях від перпендикулярної осі, на якій кріпилися підкладинки. Обертання осі з підкладками здійснювали або безперервно, або з фіксованою затримкою у випарників. Покриття обох систем відрізняються високим ступенем ламінарності шарів. Покриття системи (TiAlCrY)N/ZrN мають виражену шарувату періодичну структуру всього обсягу покриття. Період модуляції (сумарна товщина бішару) такої структури становить близько 30 нм. У покриттях системи (TiAlCrY/Zr)/(TiAlCrYN/ZrN) чітко проглядаеться два періоди модуляції. Один період приблизно збігається з періодом модуляції зразків системи (TiAlCrY/Zr) N і становить близько 30 нм. Другий період модуляції становить приблизно 1.3 мкм. У нього входить 48 бішарів. Досліджено вплив парціального тиску азоту в камері на вміст азоту в покриттях, їх твердість і адгезійну міщність. Виявлено значне збільшення твердості 68.22 ГПа і адгезійної міцності покриттів з подвійним періодом модуляції структури. Запропоновано принципово новий технологічний підхід до процесу отримання багатошарових покриттів.

Ключові слова: Багатошарові покриття, Період модуляції структури, Мікротвердість, Адгезійна міцність, Фазовий і елементний склад. 